\title{
Studies in mice on the mutagenicity of two contraceptive drugs
}

\author{
MARGARET E. WALLACE, F. M. BADR, AND R. S. BADR \\ From the Department of Genetics, University of Cambridge, Cambridge; and the Ministry of Scientific \\ Research, National Research Centre, Egypt
}

SUMMARY An experiment is described which tests for visible and invisible mutants in mice treate with four different doses each of the contraceptives Gynanovlar and Lyndiol.

The results show that there is no reason to suppose that either substance has an appreciabs mutagenic effect, expressed as an increase of antenatal and postnatal lethals or of visibles.

The substrain CBA/CagCam, used throughout, has an incidence of $0.27 \%$ of singly occurring abnormalities, mainly of the appendicular skeleton, which distinguishes it from the parent $\mathrm{CB} \AA$ strain and its axial variation described by Gruneberg (1963).

Combinations of progestins and oestrogens are used widely to prevent conception. However, in spite of numerous biological and clinical investigations (Pincus and Baily, 1964; Yen and Vela, 1968; Overbeek, 1969; Craft et al., 1970; Song et al., 1970), the mechanism of action of these substances is not completely understood.

Recent reports have shown that contraceptive drugs of steroid nature induce structural chromosomal aberration both in vivo and in vitro, and that these differ according to the type and aspect of the organism studied. For women, see Carr (1967), Goh (1967), McQuarrie et al. (1970), Badr et al. (1973). For dogs, see Williams et al. (1968); rats, Badr and Badr (1969); and onion root tips, Kabarity and Khodari (1967). For women, however, see also the null findings of Stenchever et al. (1969) and Timson (1969).

There have been no reports on the mutagenic effect of hormones at the level of gene (point) mutation in any mammal, except those concerning mice (Wolff, 1934; Wolff and Wolff, 1936; Jorg 1940), which, however, were not consistent.

The present report concerns an experiment on mice, testing two commonly used contraceptive pills for induction of mutation to both lethal and visible mutants, dominants and recessives. The method is based on a standard one (Falconer, 1949) and is not specific as to the loci to be screened.

\section{Materials}

The mice used throughout were the Cambridge substrain CBA/CagCam of the widely used Received for publication 27 September 1978
$\mathrm{CBA}^{1}$ standard inbred strain. Nine groups, each of 20 virgin females 8 to 10 weeks old, were selected, $\overrightarrow{0 \phi}$ which 8 groups were treated with drugs and one given the solvent only, was used as a control. The progeny of the sibmated generations 23 to 25 of the substrain were given nothing and so were used an overall control.

Groups I to IV were treated with Gynanovlam made by Schering (Berlin), in ascending dosage, å follows:

$\begin{array}{lll} & \mu g / \mathrm{kg} & \mu \mathrm{g} / \mathrm{kg} \\ & \begin{array}{l}\text { Norethisterone } \\ \text { acetate }\end{array} & \text { Ethinyloestradiol } \\ & 17 & \\ \text { I } & 170 & 0 \cdot 85 \\ \text { II } & 340 & 8 \cdot 5 \\ \text { III } & 680 & 17 \cdot 0 \\ \text { IV } & 34 \cdot 0\end{array}$

A second set of four groups (I to IV) were treated with Lyndiol, made by Onganon Oss. (Holland), 品 ascending dosage as follows:

$\begin{array}{lcc} & \mu g / \mathrm{kg} \text { Lynstranal } & \mu \mathrm{g} / \mathrm{kg} \text { Mestranal } \\ \text { I } & 42 & 1 \cdot 25 \\ \text { II } & 420 & 12 \cdot 5 \\ \text { III } & 840 & 25 \cdot 0 \\ \text { IV } & 1680 & 50 \cdot 0\end{array}$

The constituents of the drugs were obtained inca chemically pure form as a gift from the manufactturers, CID, and The Nile drug companies in Cair\&, Egypt. The steroids were dissolved in $40 \%$ ethanotg

${ }^{1} \mathrm{Cam}$ is the symbol for substrains maintained at the Deparitment of Genetics, Cambridge University. Substrains afe sibmated proliferations of standard inbred strains who\&e characteristics are summarised periodically (Staats, 1972). 
the solvent given to the control group was in a dose of $0.1 \mathrm{ml}$.

Administration was oral, using a soft stomach tube, and all mice received 15 consecutive daily doses. On the fifth day, treated females were mated in pairs to an untreated CBA male, or, in the case of suspected sterility, to a proven fertile CBA male. Vaginal plugs were looked for daily as a check on pregnancy and general health was noted. These observations suggested no toxic effect of either the treatments or the solvent, and no material effect on fertility after the treatment was withdrawn.

\section{Methods}

\section{BREEDING PROGRAMME}

With Falconer's design (1949) as a model, all treated females were left with their untreated CBA mates, and allowed to rear one litter. Their F1 sons were outcrossed to untreated CBA females, and their daughters backcrossed to these F1 fathers; some F1 males were also intercrossed with their sibs. The latter outcross, backcross, and intercross matings were allowed to produce three or more litters. This programme (Table 1) was used also for the control group. The backcross data were planned to be the largest, since these provide the most efficient information on the incidence of recessive mutants. The total number of young raised per group was: Gynanovlar 7935, Lyndiol 7566, and control 2130.

\section{OBSER VATIONS}

Observations on the treated females' litters, and on litters of the subsequent three types of mating, were made as follows: litter size at birth, and all deaths until weaning; each mouse in each litter was checked thoroughly for morphological abnormalities at the phenocritical ages 3,7 , and 15 days, and at weaning 25 to 31 days. Similar observations were made on control litters.

All abnormal mice were affected skeletally as shown by transparent alizarin-stained preparations. To determine whether abnormalities were inherited, an intensive breeding investigation was carried out for each affected mouse.

The control CBA generations 23 to 25 were allowed to rear as many litters as possible, the total

Table 1 Breeding programme to assess induction of lethal and visible mutations

\begin{tabular}{|c|c|c|c|}
\hline Mating type & Breeding scheme & & \\
\hline Base-line & treated $q$ & $\mathbf{x}$ & untreated $\sigma^{\star}$ \\
\hline Intercross, outcross & 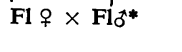 & $\begin{array}{l}x \\
1\end{array}$ & untreated \\
\hline Backcross & $\mathbf{F l} \delta^{* *}$ & $\mathbf{x}$ & F2 우 \\
\hline
\end{tabular}

being 930 . In all, some 1200 matings were made and over 20000 mice bred.

ANALYSIS OF DATA

The results fell into three sections.

Litter size and sex ratio, at birth and at weaning, were examined for the two treatments and the control, for the three generations of the main breeding programme (Table 1). These data allow assessment of the incidence of invisible (lethal) mutants induced therein.

The incidence of visible abnormalities was examined for the various parts of this programme, together with the results of breeding tests for any genetic basis of the abnormalities. These data allow assessment of the incidence of visible mutants induced therein.

Finally, litter size at birth and weaning were examined for the first three litters in generations 23 to 25 of sibmating of the CBA line, together with the incidence of abnormalities over all litters bred in these generations. These are the ultimate control data for assessing the validity of interpretations made from the main breeding programme.

Average litter sizes, with standard errors, were calculated and comparisons between averages were made by the use of Student's $t$ test, except when the size of samples differed appreciably, when the modified $t$ test (Fisher and Yates, 1960) was used. Comparisons between sex ratios were made by the use of the $2 \times 2$ contingency $\chi^{2}$ test (with Yates correction where the total was less than 500).

Similarly, comparisons between postnatal mortalities were made by the use of the contingency $\chi^{2}$ test, testing the homogeneity of observed numbers born and died, for a particular group, with the observed numbers born and died for the control.

An assessment of the incidence of invisible (lethal) mutants requires a count to be made of the numbers of antenatal and postnatal deaths in treated groups in excess of those occurring in the control group. This count has to be related to the actual number of treated gametes tested in the case of dominants, or to the 'equivalent' number in the case of recessives. The actual number is the number of F1 progeny raised. The equivalent number is derived from the number of progeny raised in backcross and intercross matings in testing each F1 gamete (Falconer, 1949). The relevant actual and equivalent numbers are given in Table 2.

\section{Results}

LITTER SIZES AND SEX RATIOS: MAIN BREEDING PROGRAMME

The progenies of the base-line, intercross, outcross, and backcross matings were examined separately. 
Table 2 No of gametes tested and size of backcross progeny examined for visible recessive mutants

\begin{tabular}{lllll}
\hline Treatment & Group & $\begin{array}{l}\text { No of F1 } \\
\text { gametes }\end{array}$ & $\begin{array}{l}\text { Equivalent } \\
\text { no of fully } \\
\text { tested } \\
\text { gametes }\end{array}$ & $\begin{array}{l}\text { No of } \\
\text { backcross } \\
\text { progeny }\end{array}$ \\
\hline Control & & 29 & $24 \cdot 21$ & 1322 \\
Gynanovlar & I & 15 & 13.07 & 800 \\
Gynanovlar & II & 28 & $25 \cdot 18$ & 1671 \\
Gynanovlar & III & 21 & $15 \cdot 90$ & 1002 \\
Gynanovlar & IV & 26 & $22 \cdot 88$ & 1619 \\
Lyndiol & I & 24 & 20.03 & 1276 \\
Lyndiol & II & 25 & 21.97 & 1468 \\
Lyndiol & III & 17 & 15.07 & 1150 \\
Lyndiol & IV & 18 & 15.47 & 1188 \\
\hline
\end{tabular}

For none of them were there consistently significant differences between any of the four dose groups and the control, for Gynanovlar or Lyndiol, in any of the following: birth litter size, weaning litter size, and sex ratio at birth and at weaning. There was an isolated significant difference (in greater postnatal mortality of Gynanovlar group III over that of the control), but this is offset by two other significant results which favour the (unlikely) beneficial effect of the treatments; these three cases fall within the number of incidently significant values which may be expected when a great number of tests is done.

\section{INCIDENCE OF VISIBLE ABNORMALITIES:}

\section{MAIN BREEDING PROGRAMME}

There were 50 visible abnormalities in the various treated groups and the control groups. But, despite extensive breeding to test heredity, the only abnormality to reappear in relations and descendants of the test programme was 'stumpy' stm (Ferguson et al., 1978). This mutant appeared among the control matings. Thus, there were no visible mutants in the whole of the main breeding programme.

The abnormalities occurred at random through the programme; the Gynanovlar rate was $0.0031 \pm$ $0 \cdot 0009$, the Lyndiol rate $0.0026 \pm 0.0011$, and the control rate $0 \cdot 0028 \pm 0 \cdot 0018$. They were distributed as follows:

$\begin{array}{lllllll} & \begin{array}{l}\text { 'Thalido- } \\ \text { mide' }\end{array} & \begin{array}{l}\text { Hydro- } \\ \text { cephalus }\end{array} & \text { Paralysis } & \begin{array}{l}\text { Tail } \\ \text { defects }\end{array} & \begin{array}{l}\text { Foot } \\ \text { defects }\end{array} & \text { Totals } \\ \text { Females } & 3 & 1 & 1 & 2 & 14 & 21 \\ \text { Males } & 0 & 2 & 0 & 3 & 23 & 28\end{array}$

The foot defects were distributed anatomically as follows:

$\begin{array}{llll}\text { Left fore } & \text { Right fore } & \text { Left hind } & \text { Right hind } \\ 3 & 3 & 14 & 17\end{array}$

LITTER SIZES AND ABNORMALITIES :

MAIN CBA LINE

Birth and weaning litter sizes, for the first three litters of matings of the 23 to 25 sibmated generations of the CBA line, were in agreement with those the main breeding programme, as also was p?eweaning mortality.

Of the 930 mice bred over all litters of these generations, one female was a hydrocephalus, and male had a short middle digit on the left fore foof; breeding tests did not establish heritability. Both were skeletal abnormalities, and the incidenceois $0.0022 \pm 0.0002$, which is in agreement with figures for the main breeding programme.

\section{Discussion}

The results preclude sex-linked or sex-limited and any other invisible mutants; they preclude also that the solvent used in the main programme produce detectable rate of mutation to invisible mutants; a appd finally they preclude any teratogenic effects.

There being no visible mutants in any of file descendants of the two treatment groups, the rate-of induction of these is zero. The actual observations for recessives are: Gynanovlar 0/77.03, Lynd $0 / 72 \cdot 54$, control $1 / 24 \cdot 21=4 \cdot 13 \%$ where $77 \cdot 03$ eRc. is the equivalent number of gametes tested, taken from Table 2. The maximum induction rate oैs obtained by the method of Stevens (1942), and-jis specifically (for the $5 \%$ level of probabilit): Gynanovlar 3.9\%, Lyndiol $4 \cdot 15 \%$, control $20 \cdot 53 \%$.

The lower $5 \%$ level for the control is $0.11 \%$; thofs, and the estimate of $4 \cdot 13 \%$, suggests, in agreemeक्षीt with Lyon et al. (1964), that the spontaneous rate may be higher than that predicted on the basis $\overline{\text { of }}$ specific locus experiments plus the estimated number of mutable loci at 5000 to 10000 .

Thus, there is no case for a gross mutagenic effect of Lyndiol or Gynanovlar.

The high rate of skeletal abnormalities throughout this work raises a query about the overall propensity of the CBA line to express skeletal defects. Unlike the defects in the notorious inbred lines C57BL a BALB/C (Bailey, 1959), they are mainly of the appendicular skeleton, whereas published infornation for the parent CBA strain (see pp. 239, 253, afd 255 of Gruneberg, 1963) describes tooth variants and axial skeleton effects. This suggests that fle Cambridge substrain now differs genetically frọm the parent strain.

However, consideration of skeletal variants adds nothing to the case for or against a more thorow investigation of the possible mutagenic effects $\mathscr{C}_{0}$ Gynanovlar and Lyndiol.

\section{References}

Badr, F. M., and Badr, R. S. (1969). Cytogenetic effect some contraceptive drugs on the nuclei of bone marew cells of the rat. Second Conference of Pharmaceutgal Science, Cairo, p. 69. 
Badr, F. M., Badr, R. S., Ibrahim, A., and Shaaban, H. S. (1973). Chromosome studies on women using oral and injectable contraceptive drugs. Medical Journal of Cairo University, 40, 37-46.

Bailey, D. W. (1959). Rates of subline divergence in highly inbred strains of mice. Journal of Heredity, 50, 26-30.

Carr, D. H. (1967). Chromosome anomalies as a cause of spontaneous abortion. American Journal of Obstetrics and Gynecology, 97, 283-293.

Craft, I. L., Wise, I. J., and Briggs, M. H. (1970). Oral contraceptives and amino acid utilisation. American Journal of Obstetrics and Gynecology, 108, 1120-1125.

Falconer, D. S. (1949). The estimation of mutation rates from incompletely tested gametes, and the detection of mutations in mammals. Journal of Genetics, 49, 226-234.

Ferguson, J. M., Wallace, M. E., and Johnson, D. R. (1978). A new type of chondrodystrophic mutant in the mouse. Journal of Medical Genetics, 15, 128-131.

Fisher, R. A., and Yates, F. (1960). Statistical Tables for Biological, Agricultural and Medical Research, 6th ed. Oliver and Boyd, Edinburgh.

Goh, K. O. (1967). Research Report of the Medical Division, Oakridge Associated Universities, Springfield. Clearing House for Federal Science and Technological Information, p. 97.

Gruneberg, H. (1963). The Pathology of Development. Blackwell, Oxford.

Jorg, H. (1940). Gibt es eine nachweisbare Erbischäbigunge der Weissen Maus Durch das 'Gonadotrophe Hypophysenvorderlappenhormone'? Zeitschrift für Geburtshilfe und Gynäkologie, 120, 147-193.

Kabarity, A., and Khodari, S. (1967). Cytological effects of two contraceptives. Genetica, 38, 184-189.

Lyon, M. F., Philips, R. J. S., and Searle, A. G. (1964). The overall rates of dominant and recessive lethal and visible mutation induced by spermatogonal $\mathrm{X}$-irradiation of mice. Genetical Research, 5, 448-467.

McQuarrie, H. G., Scott, C., Ellsworth, H. S., Harris, J. W., and Stone, R. A. (1970). Cytogenetic studies on women using oral contraceptives and their progeny. American Journal of Obstetrics and Gynecology, 108, 659-665.

Overbeek, G. A. (1969). Modern Progestation Therapy. Ed. by Z. Fastner and M. B. Morton. Round Table Conference, Rotterdam, The Netherlands.

Pincus, G., and Baily, G. (1964). Drugs used in control of reproduction. Advances in Pharmacology, 3, 285-313.

Song, J., Mark, M. S., and Lawler, M. P. (1970). Endometrial changes in women receiving oral contraceptives. American Journal of Obstetrics and Gynecology, 107, 717-728.

Staats, J. (1972). Standardized nomenclature for inbred strains of mice: fifth listing. Cancer Research, 32, 1609-1646.

Stenchever, M. A., Jarvis, J. A., and Kruger, N. K. (1969). Effect of selected oestrogen and progestin on human chromosomes in vitro. Obstetrics and Gynecology, 34, 249-251.

Stevens, W. L. (1942). Accuracy of mutation rates. Journal of Genetics, 43, 301-307.

Timson, J. (1969). Chromosomes and an oral contraceptive (Lyndiol 2.5). Journal of Reproduction and Fertility, 19, 581-583.

Williams, D. L., Runyan, J. W., and Hagen, A. A. (1968). Meiotic chromosome alterations produced by progesterone. Nature, 220, 1145-1147.

Wolff, F. (1934). Schwere Erbschädigung der weissen maus durch Hormonzufuhr. Zeitschrift fïr Geburtschilfe und Gynäkologie, 108, 246-276.

Wolff, F., and Wolff, M. (1936). Schwere Erbschädigung der weissen Maus durch Hypothysenvorderlappenhormon. Zeitschrift für Geburtschilfe und Gynäkologie, 114, 36-51.

Yen, S. S. C., and Vela, P. (1968). Effects of contraceptive steroids on carbohydrate metabolism. Journal of Clinical Endocrinology, 28, 1564-1570.

Requests for reprints to Dr M. E. Wallace, Department of Genetics, University of Cambridge, Downing Street, Cambridge CB2 3EH. 